\title{
The policy mood in Spain: The thermostat in a warm climate, 1978-2017
}

\begin{tabular}{|r|l|}
\hline Journal: & European Political Science Review \\
\hline Manuscript ID & EPSR-2019-0024.R2 \\
\hline Manuscript Type: & Research Article \\
\hline Keywords: & $\begin{array}{l}\text { Policy mood, Spain, thermostatic model, macro-polity, dynamic } \\
\text { reprresentation }\end{array}$ \\
\hline Subject Category: & Comparative Politics \\
\hline \multicolumn{2}{|l}{} \\
\hline
\end{tabular}

\section{SCHOLARONE \\ Manuscripts}




\begin{abstract}
Representative democracies are supposed to be uniquely virtuous in that they ensure that public preferences drive public policy. Dynamic representation is the outcome of a recurring interaction between electorate and parties that can be observed at the macrolevel. Preferences can shape government policy via two possible mechanisms. 'Policy accomodation' suggests that governments respond directly to the electorate's preferences. 'Electoral turnover', on the other hand, assumes that preferences shape policy indirectly. Parties pursue their ideological goals, public preferences respond 'thermostatically' by moving in the opposite direction to policy. This causes voters to switch votes and eventually leads to a turnover of power from one 'side' to 'the other'. In this paper we estimate preferences for government activity ('the policy mood') in Spain between 1978 and 2017. We show that mood responds 'thermostatically' to policy. Variations in mood are associated with support for parties. Policy is driven by party control but is not thermostatically responsive to mood. It appears that in Spain like Britain - dynamic representation can only be achieved by electoral turnover. We consider the implications of this for our understanding of how representation works.
\end{abstract}

\title{
Keywords
}

Dynamic representation, policy mood, Spain, elections, thermostatic model, macropolity 


\section{Introduction}

Representative democracies are said to be uniquely virtuous because they ensure that public preferences drive policy (May, 1978). 'Dynamic representation' is the result of the electorate and parties responding to each other over time. In this system of moving parts, preferences can shape government policy via two possible mechanisms. The 'policy accomodation' mechanism suggests that governments respond directly to the electorate's preferences. The 'electoral turnover' mechanism, on the other hand, assumes that preferences shape policy indirectly via three links. Parties pursue their ideological goals. Public preferences respond 'thermostatically' by moving in the opposite direction to policy. This, in turn, causes voters to switch votes and leads to a turnover of power from one 'side' to 'the other' (Hakhverdian, 2010; Bartle et al., 2019).

Expectations about the operation of the macro-political system are based on assumptions about the motivations of the electorate and parties. Parties are assumed to pursue office and to be willing to accommodate preferences (Strøm, 1990). Electorates are assumed to be motivated, at least in part, by policy considerations. The recurring interaction between parties and electorate, however, leads to 'feed-back' within the system. The electorate's preferences, for example, respond 'thermostatically' to actual policy, demanding 'less' as governments deliver 'more' (Wlezien, 1995). If parties are office-seeking and control policy, they can accommodate preferences by thermostatically adjusting policy (Wlezien, 1995). If they have strong ideological motivations, however, they may be unresponsive (Bartle et al., 2019). Policy can only be brought into line with preferences by replacing the government (Hakhverdian, 2010). 
Previous macro-political studies have examined the processes of dynamic representation in well-established majoritarian countries such as the US (Stimson et al., 1995) and Great Britain (Bartle et al., 2011; Bartle et al., 2019). There is little evidence about the interaction between the electorate and parties in other systems. Here we examine the case of Spain, a somewhat younger democracy, using the same methods deployed in earlier studies. We show that the Spanish electorate has moved right over time in parallel with the increase of the scope of the government activity. We demonstrate that Spanish preferences for government activity respond 'thermostatically' to policy and that these movements are associated with changes in vote intentions. While public preferences respond to policy activity, governments do not seem to respond thermostatically to preferences. While there are few constitutional limits on Spanish governments, we find that policy is not shaped by preferences but by party ideology. It seems that public preferences in Spain - just as in Great Britain - can only shape policy indirectly via electoral turnover. These findings have important implications for democratic theory and recent developments in the party system. When governments do not adjust their policy proposals to public preferences, electoral turnover is the only possible mechanism for ensuring congruence between policy and preferences. In these circumstances, democracy's promise of ensuring representative governments can only be guaranteed if the electorate can choose between parties with distinct policy platforms. The likelihood of party system breakup and the emergence of populist parties may increase when voters perceive that existing mainstream parties are enacting policy that does not match the public mood. The Spanish case may provide a good example of this. The lack of responsiveness of the Spanish governments to policy mood may have reinforced citizens' political disaffection with the existing party system. 
This may have contributed to the collapse of the Spanish two-party system in 2015 and the emergence of Podemos, Ciudadanos and, afterwards, Vox.

We structure the article as follows: in section 2 we discuss the literature on policy mood and dynamic representation. In section 3 we explain how the Spanish case adds to our understanding. In section 4 we discuss the data used to build our mood measure for Spain and the dyads ratio algorithm used to estimate mood. In section 5, we report our results. We assess whether preferences shape policy indirectly by examning the three assumed links in the electoral turnover mechanism. We also assess whether policy responds directly to prefernces as assumed by the policy accommodation mechanism. In section 6 we discuss the implications of our findings.

\section{Policy moods, thermostatic models and representation}

In order to examine dynamic representation within the macro-political system we need indicators of both public preferences and public policy over time. The estimation of preferences faces two data problems: the availability and coherence of measures. Very few countries have long series made up of responses to identical survey questions. Spain is no more fortunate in this regard than many others. Those responsible for surveys have prioritised topical rather than enduring issues. Things have improved as the power of time series research designs has become appreciated (Page and Shapiro, 1992). Institutions such as Centro de Investigaciones Sociológicas (CIS) now enable us to track shifting preferences. Nevertheless, the data in earlier years is intermittent and irregular, often consisting of short, seemingly unrelated and partially overlapping series.

Efforts to measure preferences over time have been further frustrated by the fact that political preferences appear incoherent. Individuals often express inconsistent opinions across seemingly-related issues (Zaller and Feldman, 1992). Responses to 
questions about welfare, for example, are weakly correlated to responses about taxation. Individual respondents provide contradictory responses to questions about the same issue. Minor differences in question wording and response options can produce different responses (Schuman and Presser, 1996). Indeed, respondents provide contradictory responses to the same question asked at different times (Converse, 1964). Correlations between responses to the same question at $t_{1}$ and $t_{2}$ and $t_{2}$ and $t_{3}$ are small and often no larger than those between $t_{1}$ and $t_{3}$. It appears that genuine opinion change among individuals cannot account for this variability.

The existence of measurement error implies that individual survey responses produce a lot of noise and confusing signals. Once responses are aggregated, however, random error cancels out (Page and Shapiro, 1992). While an individual's opinion in $t_{2}$ is difficult to predict from their opinions in $t_{1}$, the electorate's aggregate preferences are very predictable. Comparing responses to identical questions, moreover, eliminates nonrandom error (Stimson, 2004). Since the major parties tend to take contrasting positions on issues, moreover, preferences across diverse issues can be coded as 'left' and 'right' (Carmines and Stimson, 1990). Once done, preferences on diverse issues seem to move in parrallel. This is labelled 'the policy mood' (Stimson, 1999).

The policy mood (or 'mood') can be inferred by observing longitudinal change across series. Since many indictors provide information, breaks in individual series no longer represent an insurmountable obstacle to inferring mood. The dyads-ratio algorithm identifies a common metric by expressing preference series as ratios at two time points ('dyads') (see Appendix). It calculates all possible dyads, averages across series and weights each by their relationship with the latent variable (Stimson, 1999). ${ }^{1}$ Previous studies suggest that mood summarises preferences for 'more' or 'less' government activity (Erikson et al., 2002; Bartle et al., 2011; Stimson et al., 2012). ${ }^{2}$ 
The policy mood is one of the fundamental variables in the system of equations that describe the US macro-polity (Erikson et al., 2002). Like preferences in specific domains, it responds 'thermostatically' to government policy (Wlezien, 1995; Erikson et al., 2002). If policy overshoots the electorate's ideal point, it signals its desire for 'less' than before. If spending undershoots the ideal, the electorate signals its desire for 'more'. Preferences act like a thermostat: signalling whether the government should increase or reduce the temperature by spending 'more' or 'less'. 3

Fluctuations in mood have consequences in a system of many moving parts. In the US, the distance between candidates and average voter as indicated by mood, has a powerful effect on presidential election outcomes. The mood also influences elections to the House of Representatives and Senate (Erikson et al., 2002, pp. 256-72). In Britain, mood has an impact on annual Labour vote intentions, (Bartle et al., 2019) and Labour's general election vote share (Allen et al., 2018).

US studies of dynamic representation suggest that the policy mood has a direct impact on policy, as measured by laws and votes in Congress (Erikson et al., 2002). As the electorate signal their demand for more or less, government responds like a thermostat (Soroka and Wlezien, 2010). This suggests that a 'policy accommodation' mechanism directly connects the electorate's preferences to policy (Erikson et. al., 2002). One study of Britain came to similar conclusions (Hahkverdian, 2010). This particular analysis, however, used a single indicator of preferences (left-right selflocation) and a text-based indicator of annual policy (budget speeches in the House of Commons). Another study using estimates of the policy mood based on a wider range of preferences data and an indicator of policy based on government spending, suggests that preferences do not have a direct impact on policy. Instead, policy is shaped by party 
ideology and economic conditions (Bartle et al., 2019). Mood contributes to representation - but only indirectly via an electoral turnover mechanism.

To date, the policy mood has been estimated in the US, Great Britain, France and Italy (Stimson 1999; Bartle et al., 2011; Stimson et al., 2012; Bellucci and Pellegata, 2017). Thermostatic models of mood, moreover, have been examined only in the US and Britain (Erikson et al., 2002; Bartle et al., 2011). The responsiveness of government policy has also been examined only in those two countries ${ }^{4}$ Our understanding of dynamic representation is thus heavily dependent on these two cases. In the British case, moreover, there is disagreement about whether a policy accommodation or electoral turnover mechanism operates (Hakhverdian, 2010 c.f Bartle et al., 2019). There is a clear risk that 'US exceptionalism' may distort our understanding of how dynamic representation works. This concern is heightened by the fact that we have reasons to believe that the responsiveness of the electorate and government is conditioned by institutions: the electoral systems, degree of federalism and checks and balances and country specific factors.

Comparative studies have suggested that proportional systems produce policies closer to the preferences of the typical voter than majoritarian systems because coalitions usually contain centrist parties (Powell, 2000). It seems only natural to suggest that coalitions are also more responsive to preferences than the single party governments. Yet there are also reasons to doubt this (Wlezien and Soroka 2015a). Proportional systems lead to greater dispersion of parties and thus more extreme coalition positions (Blais and Bodet, 2006). This may lead party members to resist calls to change policy as public preferences change. Both specific preferences and the global policy mood move and are driven by policy and economic conditions. Coalitions muddy electoral accountability and may dissuade governments from responding to changing 
preferences. They may also reduce the speed of adjustment since changes need to be agreed by coalition partners. A single party government, moreover, will find it less easy to escape accountability. In plurality electoral systems small changes in vote can be magnified into large swings in seat shares. This may make single party governments responsive to preferences. Such governments find it easier to respond once 'signals' are received (Wlezien and Soroka, 2015b). Other features of the electoral system may affect responsiveness. When citizens cast their vote in single-winner districts (such as Britain and the US), only the governing or official opposition parties usually have a chance of winning the seat. The act of voting is framed in a way that favours the thermostatic hypothesis: voters express support for the current policy with the incumbent or a policy reversal with the opposition. In most advanced democracies, however, there are multiple-winner districts. This may dampen the 'signal'.

Basic constitutional designs are also likely to influence responsiveness. The US, for example, is a federal state. Many policy-making powers are reserved to the individual states. This makes it difficult for the electorate to allocate responsibility (Soroka and Wlezien, 2010). It also makes it more difficult for the federal government president and Congress - to respond to changing preferences. Britain, by contrast, is despite moves towards devolution - highly centralised. Sub-national governments are subservient to Westminster (King, 2010). This makes it puzzling why British governments do not appear to rationally accommodate preferences.

Other aspects of constitutional design may also modify government responsiveness. The US has an elaborated system of checks and balances that reduces the ability of government to respond to preferences (King, 2010). The activities of Congress and President are also subject to constitutional review by the courts. Lawmakers must factor this in when considering their response to the ebb and flow of 
public preferences. The British system, moroever, is characterised by a 'fusion' of executive and legislative power. The prime minister and cabinet usually command a majority in the House of Commons. The courts have very limited powers and ministers do not fear the 'judge over their shoulder' (King, 2010). British governments are capable of responding. This again makes it all the more puzzling that they do not appear to respond (Bartle et al.,2019).

\section{The Spanish case study}

The macro political research design provides a powerful framework to examine claims about representation. Nevertheless, it requires a great deal of data on both public preferences and policy. The Spanish case is potentially significant because it is just the fifth study of the national policy mood and only the third study of dynamic representation. It is also interesting because it is the first macro-political study of a proportional system. Elections to the Congreso use a party-list system and the d'Hondt method. The fact that there can be multiple winners in each constituency frames the choices that voters make in less clearly thermostatic ways. To be sure, the Spanish system is not entirely representative of proportional systems. The small district magnitude produces a larger seats to votes ratio and a tendency to single party government (Bosch, 2020). The Spanish constitution provides the central government with the ability to respond to changes in preferences. There are also few checks and balances. Spanish governments have the ability to respond to preferences.

To date, the number of factors that might influence the responsiveness of the electorate and governments exceeds the number or cases. It will not be possible to isolate the unique contribution of these factors until we can undertake a large $\mathrm{N}$ 
comparative study. Until we reach that point, the addition of the Spanish case is a step towards a broader understanding of dynamic representation.

The Spanish case is also an interesting case for other reasons. It is a relatively new democracy and is generally thought to be the most prominent of the early thirdwave democracies (Fishman, 2020). Among those countries, it has one of the longest histories - and vitally for our purposes - some of the best data (Gunther, Montero and Puhle 2016). It also represents the paradigmatic case of rapid welfare expansion. Just twenty years after the return of democracy and the end of the Franco regime, Spanish spending on welfare approached average European level (Boix, 1996). This could have left no time for Spanish public opinion (contrary to Britain, US and France) to evaluate policy fluctuations and respond thermostatically.

Before we apply the macro-polity framework to the Spanish case it is useful to provide a thumbnail sketch of the development of the Spanish system. There have been just five turnovers of power in 1982, 1994, 2004, 2011 and 2018 (the latter falls outside the period for which we have data). The first turnover was not a simple transfer from one 'side' to another. The transition government that ruled Spain from 1976 to 1982 was made up of the reformists of the old regime (such as Presidents Adolfo Suárez and Leopoldo Calvo-Sotelo) under the umbrella of the UCD (Unión de Centro Democrático). Its essential task was to consolidate the democratic regime and meet European standards for the political and economic systems (Powell, 2009). From our current perspective it may seem a rather right-wing government. At that time, however, it was a reformist project.

Felipe González’s Partido Socialista Obrero Español (PSOE) were social democrats who formed governments for fourteen years from 1982 to 1996 . The PSOE 
won four consecutive election victories. This government adopted standard social democratic policies and increased spending on welfare. It expanded universal health care and education. It also significantly increased old-age transfers through noncontributory pensions. As a result, Spain was one of the few countries in which inequality decreased in the 1980s. During the UCD and Socialist governments, fiscal revenues also increased considerably and, as a result, tax burden increased more than ten percentage points from 1977 to 1992 (Fernández-Albertos, 2012).

The PSOE was replaced by the conservative Partido Popular (PP) led by José María Aznar between 1996 and 2004. This government focussed on achieving economic stability and promoted market solutions. It was in turn replaced by the PSOE, led by Rodríguez Zapatero. The new socialist government mainly focused on issues such as the territorial reform and, especially, the promotion of the social and civil rights (such as gay marriage and recognition of the Franco dictatorship victims) (SánchezCuenca, 2012). It increased the minimum wage and old-age pensions, expanded paternity leave and implemented new disability laws (Bernardi and Sarasa, 2009)

Economic issues dominated Zapatero's second government. It tried to elude the Great Recession of the late 2000s by increasing public spending and implementing public works programmes (Gunther and Montero, 2009; Urquizu, 2014). It then announced a U-turn. The stimulus program ended, public wages were cut and pensions frozen (Fernández-Albertos, 2012). It was replaced in 2011 by a new PP government, led by Mariano Rajoy. This continued to implement the austerity policies in line with Spain's membership of the euro-zone. This government lost its majority in 2016 and collapsed in 2018. It was replaced by PSOE after losing a vote of non-confidence. 
The economic crisis of 2008 rapidly turned into a political crisis. Political distrust in all political institutions (parliament, government, EU and political parties) peaked during the 2010-12 period, when the economic crisis hit hardest (Orriols and Rico, 2014). The two-party systems dominated by PP and PSOE was eroded in the 2015 general elections. The economic crisis (Bosch and Duran, 2019) and political disaffection and distrust (Orriols and Cordero, 2016) led to the emergence of two new parties in the 2014-16 period: the left-wing Podemos and the centre-right Ciudadanos.

\section{Data and methods}

Our methodology replicates that used in the US, Britain and France (Stimson 1999; Bartle et al., 2011; Stimson et al., 2012). ${ }^{5}$

\subsection{Preferences and mood}

The database that is used to estimate mood consists of marginal responses to survey items that measure preferences on controversial issues (Stokes, 1963). These include those that touch on the traditional left-right battles between government intervention and the free market, the welfare state, public versus private ownership, public spending, taxation and poverty and inequality. It also includes preferences on law and order, moral attitudes, abortion, post-materialism, race and immigration, the environment, defence, Europe and left-right self-placement. ${ }^{6}$ The database includes unambiguous indicators of preference, such as the CIS 'forced choice' question about devolution that asks respondents to choose between 'a national government without regions', 'regions with less powers', 'regions with the same powers as now', 'regions with more powers' and 'regions with the right of independence'. It also includes a large number of 'Likert-type' items that invite respondents to agree or disagree with statements. These responses 
imply preferences: those who agree that 'homosexuality is a disease', for example, are likely to oppose liberalisation (Ellis and Stimson, 2012).

The algorithm used to estimate mood uses information about changing preferences to estimate the annual mood. Accordingly, only items that are repeated in more than one year can be used for estimation. Responses to each item were coded from 0 (most right-wing) to 11 (most left-wing), with 5 as the neutral point. The coding of responses is potentially controversial since there may be genuine disagreement in some cases about whether a position is left or right. In practice these decisions are generally simple because the parties take positions on issues that are important to voters (Carmines and Stimson, 1990). While the normative question of what positions are 'really' appropriate for those on the left and right absorb the attention of political theorists, the objective question of what is left and right in relation to party competition is solved for us by the parties. The left-right dimension is a 'party defined space' (Budge and Farlie, 1977). Spanish politics has been dominated by two major parties since the mid-1980s. The problem of how to code responses boils down to assigning the PSOE position and PP position to each issue on the understanding that these parties take opposing positions on most controversial issues. Coding responses is simply a way of establishing the 'polarity' of the items and does not force items onto a single left-right dimension. If items exhibit distinctive longitudinal movements - that are not shared with other series - the algorithm will identify this.

We include the respondents' self-reported left-right positions with some hestitation. Describing oneself as 'left' or 'right' need not imply a preference (Ellis and Stimson, 2012). Nevertheless, there are good reasons for believing that longitudinal changes in the number of self-declared left- or right-wingers reflect changes in preferences. In Great Britain left-right self-reported positions correlate with the policy 
mood (Bartle et al., 2011, p. 273). The same is true in France (Stimson et al., 2012, p. 302). Previous studies, moreover, have relied on such indicators as a measure of mood (Hakhverdian, 2010). Accordingly, we treat this as an empirical issue. If left-right selfpositions do not track other preferences this is something that the algorithm will identify. This decision allows us to make use of a large amount of data on left-right self-location. It also extends our time series since it is the only evidence of preferences available between 1978 and 1981.

\section{Table 1}

A couple of decisions to include or exclude items need further justification. Unlike the US case study (Erikson et al., 2002, p. 201), we decided to include survey questions on foreign affairs. International issues have, in many instances, divided the major parties in Spain. This was especially so since 2002, when the PP government aligned with the US foreign policy in the Middle East. The PSOE, by contrast, was less supportive of US foreign policy than PP (Del Arenal, 2008). In accordance with our general strategy of 'letting the data decide' we include foreign affairs items in our database. ${ }^{7}$ We removed all survey questions whose wordings include references to named parties or politicians because we want to avoid those preferences which are excessively polluted by party or leader evaluations (Stimson, 1999). Those questions that refer to 'government' are a special case and require a degree of interpretative judgement. Those that clearly refer to a specific administration are excluded. Those that refer to 'the government' in the abstract are retained. 
The items that were finally included were collected by five survey houses: Centro de Investigaciones Sociológicas (CIS), Eurobarometer (EB), the European Social Survey (ESS), the Role of Government survey (RG) and the World Values Survey (WVS). Table 1 displays the number of unique questions asked by these houses and the number of administrations (times that questions were asked). The database is dominated by the CIS. This source supplies around 58 per cent of all questions and 79 per cent of all administrations. Figure 1 displays the number of administrations of survey questions per year. The data is thin in the late 1970s but much richer later on, with between 30 and 90 administrations per year from the mid-1980s onwards (with the partial exception of the early 2000s when there are around 20). Averaging over a large number of questions, provides a reliable indicator of the underlying mood.

The data is drawn from nationally representative studies between 1978 and 2017. Accordingly, we exclude data relating only to specific regions such as Catalonia. The final preferences data set consists of 127 survey items asked in 1671 separate administrations. On average each survey item was asked in 13 administrations. ${ }^{8}$ This statistic conceals considerable variation. ${ }^{9}$ One question on left-right self-placement was asked more than three-hundred times, while some items were asked just twice. The longer series contribute more information about mood.

Figure 1

\subsection{Policy}

In order to test thermostatic models we need to develop an indicator of policy that is analogous to mood. Policy can be defined as the cumulative 'total sum of laws and 
regulations regarding the particular set of issues' (Erikson et al., 2002, p. 285). This concept is difficult to summarise in a single measure. Governments make many laws and regulations over a wide range of issues. They legislate, enter into treaties, make administrative decisions and tax and spend. In principle, policy can be indicated by words and/or deeds. In the Spanish case there is no obvious text-based indicator of annual policy. Even if we had such data, moreover, the validity of such text-based indicators of policy position would depend on assumptions of unknown validity (Laver et al., 2003; Lowe, 2008). We anticipate that preferences respond to delivered rather than promised policy. ${ }^{10}$ Most, though by no means all, issues reflect the fundamental disagreement between parties about government activity. In general, the PSOE favours more activity and the PP favours less. Most activity involves spending. Total public spending provides a convenient way of summarising policy (Bartle et al., 2019).

Our indicator of government activity is total outlays (disbursements) of general government as a percentage of GDP as reported by the OECD. In general, parties of the left prefer higher spending than the PP. In some issue domains, however, these preferences are reversed. The PSOE, for example, prefer less spending on defence. Since the return of democracy defence spending has ranged from a high of 3 per cent of GDP in 1984 to just 1.2 per cent in 2016 according to SIPRI data. In order to provide an indicator of policy that is analogous to our measure of mood, we subtract defence spending from total outlays in order to produce an indicator that we call Non-Military Government Expenditure (NMGE). Annual NMGE is displayed in Figure 2 (Bartle et al., 2019). There has been a general increase in spending since 1976 but there were visible reductions between 1993 and 2001. Spending levelled off in the early to mid2000s and rapidly increased following the financial crash up to 2012. Spending then fell until 2017 under the austerity programme followed by the Rajoy PP government. 
Figure 2

Figure 2 contains a great deal of information. In Figure 3 we simplify this to show how NMGE has varied by the five administrations between 1978 and 2017. This visual evidence suggests that the two governing parties have pursued their ideological goals. The transitional UCD government increased NMGE by fully 8.9 points between 1976 and 1982. The PSOE increased NMGE by 6.2 and 7.2 points respectively during their periods in office. The PP, by contrast, reduced NMGE by 4.3 and 5.0 points respectively. Some of the increase under the PSOE between 2004 and 2011, however, was a response to the economic crisis. NMGE was static between 2004 and 2007 at around 37 per cent of GDP. It rose to 40 per cent in 2008 and 45 per cent by 2011 .

Figure 3

\subsection{Economic conditions}

Studies in the US and Britain have suggested that the mood responds to economic conditions. As unemployment increases, mood moves left as the electorate signal their desire for action to get people back to work. Accordingly, we control for unemployment in order to estimate the unique impact of discretionary policy on mood. The unemployment rate is measured by data compiled by the National Statistics Institute (INE) through its Economically Active Population Survey (EPA). 


\subsection{Party control of government}

Mood may also respond to party control of government. Some components of policy are not properly captured by spending. Some of the variation in mood represents a rejection of government positions. To measure party control, we use a trichotomous variable scored as ' 1 ' in years PSOE is in power, ' 0 ' in years of right-wing (UCD or PP) rule and ' 0.5 ' in those years when there is a turnover of government.

\subsection{Vote intentions}

In the macro-polity made up of many moving parts, mood has both causes and consequences. We examine whether the fluctuations in mood influences support for parties. Our indicator of support is mean annual vote intention based on quarterly CIS data. Since the Spanish system has undergone a series of reconfigurations, we combine annual vote intentions for parties of the right and left. For most of the period, the right is largely PP and the left is largely the PSOE. We also explore the Pearson's correlation between mood and party vote in general elections. In this case the $\mathrm{N}$ is limited by the number of elections and the age of the party. The PP, for example, first contested the 1988 general election and have contested just nine general elections.

\section{5 Statistical models}

Time series models enable us to track the dynamics of preferences and policy. The nature of the time series, however, raises issues. In particular, when we inspect the mood, vote intentions and domestic spending series, we find that these variables are not stationary: the mean score moves over time. Non-stationarity creates the problem of spurious regression (Enders, 2004). Two non-stationary variables are likely to correlate significantly, even if they are unrelated. 
One approach to the problem of non-stationarity is to model relationships using error correction models (De Boef and Keele, 2008; Keele et al., 2016). We difference the series until we have a stationary time series.

$\Delta \mathrm{Y}_{\mathrm{t}}=\mathrm{b}_{0}+\mathrm{b}_{1} \Delta \mathrm{X}_{\mathrm{t}}+\mathrm{a}\left(\mathrm{Y}_{\mathrm{t}-1}-\mathrm{g}_{0}-\mathrm{g}_{1} \mathrm{X}_{\mathrm{t}-1}\right)$

This assumes that there is a long-term equilibrium relationship between the variables. The further out of equilibrium we are the larger the adjustment (the parameter a represents the speed of this adjustment). Error correction models are appropriate with non-stationary data if the variables are co-integrated (Engle and Granger, 1987). Roughly speaking, this means that the variables move up and down in parallel, and the relationship remains approximately the same over the whole time period.

We use the error correction model whenever we identify a co-integrating relationship. We identify this in two ways. We perform an augmented Dickey-Fuller test (Enders 2004). We also establish whether the error correction parameter is significant. When using the augmented Dickey-Fuller test as a test for co-integration, we use the distribution derived by MacKinnon (1994) and Ericsson and MacKinnon (2002) (see Grant and Lebo, 2016). We find evidence of co-integration in our models with mood, vote intentions and NMGE as the dependent variable, and use error correction models in these cases.

\section{Empirical Findings}

In this section 5.1 we lay out our estimates of mood. In the following three sub-sections we assess whether preferences shape policy indirectly via an 'electoral turnover' mechanism. More specifically, we assess whether public preferences respond to policy (in section 5.2), whether votes respond to preferences (in 5.3) and finally whether policy 
responds to party control (in section 5.4). We also assess the 'policy accommodation' model by determining if policy respond directly to mood.

\subsection{The estimated mood}

The preferences data, comprising of 127 separate series and 1671 separate administrations, enables us to generate a large number of dyadic comparisons. This produces an estimate of the mood for each year between 1978 and 2017. About 45 per cent of all variance in observed preferences is common to this mood. The remaining 55 per cent is either specific to the particular issue domain, item-specific or a function of the specific wording of each question (Erikson et al., 2002, p. 203). ${ }^{11}$

In order to illustrate the content of mood, we briefly examine the factor loadings for individual items on the estimated mood series. There are 127 series. It is not easy to interpret all the loadings. Since the series vary in length and their relationship with mood, it would be misleading to examine all loadings. Table 2 displays the loadings for the preference items that are entered in the database in at least ten years and load at 0.5 or above. In total there are 15 items that meet these joint requirements. Fully 13 of these items relate to government activity as monitored by the CIS, including spending on infrastructure, pensions, culture, transport, public security and the environment. These are exactly the sorts of issues that the PSOE and the PP have always disagreed about.

The remaining two items that satisfy the joint conditions for inclusion in table 2 relate to support for European unity and left-right self-placement. The prominence of the European issue in this table suggests that it may have been folded into a general leftright dimension (Carmines and Stimson, 1990). This replicates findings in Britain (Bartle et al., 2011). The loadings for left-right self-placement suggest that, in Spain just as in Britain and France - left-right self-placement tracks other preferences. 
Figure 4

The series is calibrated so that 50 represents a balance of left and right responses. Scores above 50 indicate that the mood is on balance left. Scores below 50 indicate that the mood is right. Figure 4 suggests that the Spanish electorate has been left throughout the 39 years for which we have data. Nevertheless, the electorate's mood trended to the right across this period. Within this overall picture there are a series of distinct movements. The mood shifted sharply left between 2003 and 2004, just before PSOE's return to power. It then tracked right until 2011, when it shifted left again, peaking in 2015 . The mood then fell back to the right by 2017 , though this may be a product of the small amount of data available to use in that year (see Figure 1). ${ }^{12}$

Figure 5

Figure 4 contains a lot of detail about the annual policy mood. Figure 5 summarises the variations in mood by government. This shows that the mood moved right under the transitional UCD government and both PSOE governments. Conversely, it moved left under both PP administrations. If we take party as a rough indicator of policy (left under UCD and PSOE, right under PP) this provides some initial support for the thermostatic hypothesis. Party control of government is, however, an imperfect indicator of policy. In the next section we directly examine whether the electorate respond thermostatically to policy using our spending-based measure (NMGE). 


\subsection{What drives mood?}

Before we formally model the policy mood, we must take into account the fact that the mood series is not stationary. The augmented Dickey fuller for the raw mood is $-2.04 .{ }^{13}$ This is less than the critical value of -3.662 . The augmented Dickey fuller for the first difference of the policy mood is -7.15. This suggests that an ECM specification, with the first difference as the dependent variable, is appropriate. ECMs assume that the major path of causality between two variables is that the explanatory variables create a dynamic equilibrium for the variable to be explained. The unit root variable (Y) is thought to equilibrate to a level dependent on the level of the causal series (X). When disturbed by some exogenous condition or event, it will tend to equilibrate, but to the dynamic target set by the explanatory variable, not to a fixed mean. The evidence for dynamic equilibration is (1) that significant relationships that are observed between the level of the explanatory series and change in the dependent series (the 'long-term' effects), and (2) the error correction phenomenon, where changes in the dependent variable are negatively related to previous deviations from dynamic equilibrium.

\section{Table 3}

Table 3 displays a series of error correction models. ${ }^{14}$ Model 3.1 simply examines the impact of party control on mood. The negative coefficient for the error correction term is correctly signed and supports an ECM specification. The negative coefficient for the party control variable suggests that the mood moves right under PSOE and left under PP/UCD governments. The coefficient for control ( $b=-1.47)$, 
however, is not large. Both it and the error correction coefficient are statistically significant only at the generous threshold of $\mathrm{p}<0.1$.

Model 3.2 adds logged indicators of policy and economic conditions to the equation. ${ }^{15}$ Neither of the coefficients for short-term effects of NMGE and unemployment are statistically significant. The coefficients for the long-term effects of NMGE ( $b=-16.11)$ and unemployment $(b=0.23)$ are both correctly signed but only NMGE is statistically significant at $\mathrm{p}<0.1$. The coefficient for party control $(b=-0.67)$ is no longer significant. This is omitted in Model 3.3. The long-term effects for both NMGE $(b=19.75)$ and unemployment $(b=3.61)$ have the correct (and statistically significant) relationships with mood. The fit of this model is low $\left(\mathrm{R}^{2}=0.17\right)$ but similar to ECM models for Britain (Bartle et al., 2011). Model 3.4 finally adds a dummy variable to account for the steep increase that we observe in figure 2 around 2004. The adjusted $\mathrm{R}^{2}$ for this model increases substantially to 0.31 . The coefficient for this variable is both large $(b=6.11)$ and statistically significant $(\mathrm{p}<0.01)$. The coefficients for both the long-term effects of both NMGE $(b=-18.80)$ and unemployment $(b=4.06)$ are also both larger and more significant. ${ }^{16}$

Predicting first differences is challenging. All in all, however, these results provide support for the thermostatic hypothesis in relation to the responsiveness of the electorate. ${ }^{17}$ While figure 5 provides the impression that party control of government alone influences mood, it does not have an effect net of policy and economic conditions. The swing of preferences for government activity is caused by policy (NMGE).

These findings provide a reassuring story about public responsiveness. Preferences are driven by policy (Soroka and Wlezien, 2010). The electorate displays a collective responsiveness that is surprising given what we know about the 'typical 
individual' (Erikson et al., 2002). In the next section, we examine whether variations in mood have consequences for another form of mass political behaviour.

\subsection{What are the consequences of mood for vote intentions?}

Mood is one of the most important variables in the system of equations that make up the US macro-political system (Erikson et al., 2002). We now examine its impact on vote intentions. We need to be cautious about interpreting our findings since we are not able to control for other factors that might influence vote, such as evaluations of party competence (Green and Jennings, 2012) and evaluations of party leaders (King, 2002). The time series evidence about these concepts, however, is too fragmentary to incorporate in our annual vote intention models.

Vote intentions for parties of the left and parties of the right are both unit roots. The Dickey-Fuller statistic for left vote intentions is -2.853 and that for the right is 1.463. The Dickey-Fuller statistics for the first differences are -6.212 and -4.094 respectively, suggesting that error correction specifications with the first difference as the dependent variable are appropriate.

Table 4

Table 4 reports models of annual vote intentions for parties of the left and right between 1978 and 2017. The models clearly suggest that logged value of lagged unsmoothed mood has significant short-term and long-term effects on annual vote intentions for the left and right. The positive coefficients for mood in the left vote intentions model (short-term $b=41.04$ and long-term $b=14.04$ ) suggest that as the mood 
moves left, support for parties of the left increase. The negative coefficients for mood in the right vote intentions vote model (short-term $b=-38.49$ and long-term $b=-17.59$ ) suggest that as the mood moves left, support for the parties of the right decrease. ${ }^{18}$

The evidence further suggests that mood is associated with general election vote shares. The Pearson's correlation between mood and vote for the PSOE is $0.33(\mathrm{~N}=17)$, while that for the PP is $0.87(\mathrm{~N}=17)$. There are more forces that influence general election outcomes. Movements in mood, however, appear to have electoral consequences. This evidence provides further support for the proposed electoral connection.

\section{4 What are the consequences of party control and policy mood for policy?}

To this point we have established the first two links in the electoral turnover mechanism. In this section we assess what drives policy. If party control drives policy the electoral turnover mechanism will be supported. If mood drives policy, the policy accommodation mechanism will be supported.

Table 5 displays the results of a series of regressions that are designed to test whether policy responds thermostatically to party control, unemployment and mood (as the 'policy accommodation' hypothesis suggests). Model 5.1 provides a test of the hypothesis that policy is simply a function of party control: that parties of the left spend more than parties of the right. The coefficient for control $(b=0.99)$ is correctly signed and statistically significant. It remains so as we add controls for logged lagged unemployment in Model 5.2 and logged lagged mood in Model 5.3. The finding that 'party matters' to policy is robust (Blais et al., 1993, 1996 cf. Rose, 1980). 


\section{Table 5}

Model 5.2 provides a test of the hypothesis that spending rises as a result of unemployment. This is confirmed in the short-term $(b=6.15)$ but not in the long-term ( $b=0.22$ and is statistically insignificant). These findings persist when we add controls for mood in model 5.3. This final model tests the proposition that spending responds thermostatically to movements in mood as proposed in the policy accommodation mechanism (Erikson et al., 2002; Bartle et al., 2019). This can be rejected in both the short and long-terms. The coefficients ( $b=4.41$ and -4.21 respectively) are both statistically insignificant. Spanish governments respond to public by paying more attention to the 'most important issue', particularly where the government has a clear responsibility (Chaqués Bonafont and Palau, 2011). This attention, however, does not appear to translate into policy activity, at least as measured by spending.

These findings suggest that mood is thermostatically responsive to policy. The reverse, however, is not true: policy is not thermostatically responsive to mood. This asymmetry suggests that Spanish macro-polity is similar to Britain and different from the US (Bartle et al., 2019; Erikson et al., 2002). It may also suggest that US findings are exceptional and unrepresentative of how representation works in macro-political systems. Political scientists should not assume that policy accommodation produces dynamic representation everywhere. We need further case studies before drawing general conclusions. In the meantime, this study provides a useful template to follow.

\section{Discussion}


The measures of policy in the US, Great Britain and Spain are not equivalent. US studies incorporated congressional rating scales and congressional role call outcomes (Stimson et al., 1995; Erikson et al., 2002, pp. 294-6). They did not examine spending. The different findings may be the result of these differences. Policy is a combination of what governments say and do. Policy activity includes both legislative votes and legislation. Rating scales are not available for Great Britain or Spain. Roll call votes, moreover, make little sense in systems such as Westminster and the Congresso where party loyalty is strong.

If we are to understand how institutions condition the macro-polity of moving parts, the next generation of studies should focus on producing cross-national indicators of policy analogous to mood. Government spending as a proportion of GDP seems an appropriate indicator. It gets to the heart of the main dimension of political competition in most countries. To be sure, not all policy involves spending but a lot - even most of it - does. Equivalent measures of spending are widely available. Money and GDP are obvious numeraires. Spending is likely to loom large in most comparative studies.

There are some texts that provide a basis for comparison of policy and representation across systems. Party programmes provide the basis for government policy. To be sure, promises and delivered policy are not the same, particularly given the complexities of coalitions. Nevertheless, the cross-national Manifesto Research on Political Representation (MARPOR) group has conveniently analysed the text of party programmes and produced a summary measure that is tolerably analogous to mood. If parties are office seeking, we might expect party positions to correlate with the mood.

The right-left (RILE) scores that summarise party positions are estimated by allocating each sentence or quasi-sentence into one of 56 coding categories (Budge et 
al. 2001). Thirteen of these categories are designated as 'right' and thirteen as 'left'. The latter are subtracted from the former to calculate the overall RILE score. The higher the score, the more right-wing the party's position. This measure has a degree of face validity and proven useful in a wide range of studies (Budge et al., 2001).

The Pearson's correlation between Spanish mood and PSOE RILE scores is 0.39 $(\mathrm{N}=11) .{ }^{19}$ This suggests that the PSOE moves in the opposite direction to mood. The correlation between mood and PP RILE score, on the other hand, is $-0.38(\mathrm{~N}=8)$. The PP has tracked mood to a degree. This replicates British findings (Allen et al., 2018). For the moment at least, it appears that parties of the right track mood better than parties of the left. This does not tell us, of course, which party was closer to the average elector at any point in time. If we could find somewhere of recalibrating both series on the same metric we would be able to establish just how close the parties were to the mood (Erikson et al., 2002). For the moment it seems that the PPs policy promises are more sensitive to the mood than the PSOE. Over time this ought to mean that the electorate is closer to the PP than before. This may account for its improved electoral performance.

\section{Conclusion}

This paper has examined the role of the policy mood in the Spanish system between 1978 and 2017 using a wealth of data. The Spanish electorate have tended to move right over-time in response to both government policy and economic conditions. Since the scope of government activity - as measured by NMGE and other indicators - has increased over time, this sustained thermostatic response provides a plausible explanation of the rightward drift of the electorate (Wlezien, 1995, Soroka and Wlezien, 2010). This is an important finding: Spanish public preferences reflect policy activity. 
Since Spanish governments are thermostatically unresponsive to mood, the only way that policy can be brought into line with preferences is via a turnover of power from one 'side' to 'the other'. The fact that votes respond to preferences suggests that mood may indirectly influence policy. To be sure, a government whose basic policy programme is out of line with preferences may win re-election if it enjoys a reputation for competence (Green and Jennings, 2012). When it loses this reputation, as a result of poor performance or 'the costs of ruling', the turnover of power from one 'side' to another may bring preferences back into line over time (Bartle et al., 2019).

While the electorate are responsive to policy, party policy does not appear to be thermostatically responsive to the mood. This is a striking finding in the British and Spanish case because there are few constitutional limits on government. Policy inertia may make it difficult to respond or reverse policy when needed (Wilson, 2000). It may simply be that parties are rather more policy and rather less office-seeking than widely assumed (Strøm, 1990). Even if parties are aware of the mood they may ignore it and pursue ideological goals to satisfy their members. Parties, after all, rely on those members for funds and campaigns. They cannot easily modulate policy in response to electoral preferences (Budge, 1994). Parties may also be ignorant of the mood and not sense these long-term shifts in opinion across seemingly unrelated issues. The two explanations, of course, may be inter-related. Ideology provides the emotional basis for the sort of 'motivated reasoning' (Epley and Giolvich, 2016). Strong ideological motivations may lead to a distorted impression of public opinion.

The lack of responsiveness may be a factor behind citizens' disaffection with the system and distrust of political parties. It may even be a factor behind the collapse of the two-party system in 2015 and the emergence of new parties, Podemos and Ciudadanos, with political and democratic regeneration agendas. Policy is often moving in the 
opposite direction to preferences. Political distrust after the Great Recession certainly appears to have been caused by citizens' feelings that system was unresponsive (Torcal, 2014). A great deal of research shows that Spaniards are dissatisfied with how their MP represents citizens' interests (Delgado et al., 1998; Méndez-Lago and Martínez, 2002). Voting for Podemos in 2015 was associated with the belief that politicians do not care much with what people think (Rodríguez-Teruel et al., 2018a). Similarly, voting for Ciudadanos was correlated with thinking that politicians pursue their own self-interest (Rodríguez-Teruel and Barrio, 2018b).

If this is a general phenomenon across representative democracies, we tentatively suggest that the prolonged unresponsiveness of policy to mood may account for the rise of populist politicians, especially after the economic crisis that further limits governments' ability to respond. This important change in the political supply may reverse the situation and make the Spanish democracy more responsive to citizens' preferences. We must be careful, however, not to claim too much. Our study, deals with long-term evolution of policy mood. For the moment we lack sufficient information to determine the potential effects of the party system change on policy responsiveness. This does, however, appear to represent a potentially rich research agenda.

\footnotetext{
${ }^{1}$ The mood can also be estimated by McGann's (2014) estimated based on itemresponse theory. The two methods produce very similar results.

2 There is also some research relating to the Netherlands, and some subnational territories (see McGann et al., 2019; Romero-Vidal, 2019).

${ }^{3}$ It is not necessary that the whole electorate shift their political preferences in order to click the thermostat: the shift of centrists may tip the balance left or right. ${ }^{4}$ Soroka and Wlezien (2010) examine responsiveness in the US, UK and Canada in relation to specific policy domains. They were not able to examine responsiveness in relation to welfare in the UK.
} 
${ }^{5}$ The whole database is available for the purpose of research verification in the following link: link removed to ensure anonymity

${ }^{6}$ One reviewer questioned the inclusion of left-right self-placement and environmental issues. In total left-right items constitute almost one third of all our data (482 out of 1681 administrations). They provides some of the longest evidence about preferences from 1978 right through to 2017 . Omitting these indicators produces very different results but makes little sense given that it loads highly on the mood. We also know that in Great Britain and France self-locations track other preferences (Bartle et al., 2011; Stimson et al., 2012). We do not regard it as problematic to code pro-environment positions as left given the well-established of parties of the left to advocate protection. In the present case, moreover, most of the items actually relate to spending (or cuts) in the domain of the environment. These items might just as easily be coded as spending items. There are just 10 items and 61 administrations. In any event, omitting them makes little difference to the mood estimates.

${ }^{7}$ The five items that are included relate to support for foreign aid and represent just 36 administrations - just 2 per cent of the database.

${ }^{8}$ A similar amount of data was used to estimate the US mood (Erikson et al., 2002, p. 201).

${ }^{9}$ From 1978 to 1980 we only have data on left-right self-location. Since this loads very highly on the extracted series we feel justified in estimating mood in those years.

${ }^{10}$ Soroka and Wlezien (2010) show that publics respond to actual spending rather than appropriations.

${ }^{11}$ We have also estimated a second dimension. This is less easy to interpret and explains far less of the variation.

$12 \mathrm{Bi}$-annual estimates of the mood produce similar results.

${ }^{13}$ The ADF statistics reported here are for the unsmoothed series. The statistics for the smoothed series are -1.839 for the raw series and -5.574 for the first difference of the series.

${ }^{14}$ We take the logs of continuous variables in order to deal with heteroscedasticity.

15 The models for smoothed mood produce results very similar to those for the unsmoothed series.

${ }^{16}$ Replacing NMGE with the a variable simply measuring outlays, without subtracting defence spending, produces very similar but less strong results. This emphasises the need to distinguish between types of spending.

${ }^{17}$ We have more confidence in the finding about the impact of spending than unemployment. Replacing NMGE with outlays produces a slightly poorer fit but unemployment is still significant at $\mathrm{p}<0.1$. It ceases to be significant if we replace NMGE with the General government final consumption expenditure as a percentage of GDP as reported by the World Bank.

18 The right model appears so suffer from autocorrelation according to the Breusch

Godfrey statistic but passes the simpler Portmanteau test.

${ }^{19}$ The data on party programmes was downloaded from: https://manifestoproject.wzb.eu/datasets 


\section{References}

Allen, N., Bartle, J. and Quinn, T. (2018) The impact of the policy mood on party competition and election outcomes in Great Britain, 1945-2015. Paper presented at the Elections, Public Opinion and Parties conference Royal Holloway, University of London, September 2018.

Bartle, J., Avellaneda, S.D. and McGann, A. (2019) 'Policy accommodation versus electoral turnover: policy representation in Britain, 1945-2015' Journal of Public Policy, 39(2), pp. 235-265. doi: 10.1017/S0143814X18000090.

Bartle, J.; Dellepiane Avellaneda, S. and Stimson, J.A. (2011) 'The moving centre: Preferences for government activity in Britain, 1950-2005'. British Journal of Political Science, 41(2), pp. 259-85.

Bellucci, P. and Pellegata, A. (2017) 'Citizens' policy mood, policies and election outcomes in Italy’, Contemporary Italian Politics, 9(1), pp. 8-29.

Bernardi, F. and Sarasa, S. (2009) 'Las nuevas políticas sociales del Gobierno de Zapatero' in Sánchez-Cuenca, I. and Bosco, A. (eds) La España de Zapatero. Años de cambios 2004-2008, pp: 227-248. Madrid: Editorial Pablo Iglesias.

Blais, A. and Bodet, A. (2006) 'Does proportional representation foster closer congruence between citizens and policymakers?', Comparative Political Studies, 39(10), pp. 1243-62.

Blais, A. Blake, D. and Dion, S. (1993) 'Do parties make a difference? Parties and the Size of Government in Liberal Democracies', American Journal of Political Science, 37(1), pp. 40-62.

Blais, A., Blake, D. and Dion, S. (1996) 'Do parties make a difference? A reappraisal', American Journal of Political Science, 40(2), pp. 514-20.

Boix, C. (1996) Partidos políticos, crecimiento e igualdad: estrategias económicas conservadoras y socialdemócratas en la economía mundial. Madrid: Alianza Universidad.

Bosch, A. (2020) 'The Spanish Electoral System' in Muro, D. and Lago, I. (eds.) The Oxford Handbook of Spanish Politics, ch. 23, pp. 387-407. Oxford: Oxford University Press.

Bosch, A. and Duran, I.M. (2019) 'How does economic crisis impel emerging parties on the road to elections? The case of the Spanish Podemos and Ciudadanos' in Party Politics, 25(2), pp: 257-267. doi.org/10.1177/1354068817710223

Budge, I (1994) 'A new spatial theory of party competition: Uncertainty, ideology and policy equilibria viewed comparatively and temporally', British Journal of Political Science, vol. 24(4), 443-467.

Budge, I. and Farlie, D. (1977) Voting and Party Competition. London: Wiley. 
Budge, I., Klingemann, H.D., Volkens, A., Bara, J. and Tanenbaum, E. (2001) Mapping Policy Preferences: Estimates for Parties, Electors, and Governments 1945-1998, Oxford: Oxford University Press.

Carmines, E.G. and Stimson, J.A. (1990) Issue Evolution: Race and the Transformation of American Politics. Cambridge: Cambridge University Press.

Chaqués Bonafont, L. and Palau, A.M. (2011) 'Assessing the Responsiveness of Spanish Policymakers to the Priorities of their Citizens' in West European Politics, 34(4), pp. 706-730.

Converse, P.E, (1964) 'The Nature of Belief Systems in Mass Publics', Apter, D.E. (ed.) Ideology and Discontent. New York: Free Press

De Boef, S. and Keele, L. (2008) 'Taking time seriously', American Journal of Political Science, 52(1), pp. 184-200.

Del Arenal, C. (2008) 'Consenso y disenso en la política exterior de España'. Working paper no 25/2008. Madrid: Real Instituto Elcano.

Delgado, I.; Martínez, A. and Oñate, P. (1998) Parlamento y opinión pública en España. Madrid: Centro de Investigaciones Sociológicas.

Ellis, C. and Stimson, J.A. (2012) Political Ideology in America. Cambridge: Cambridge University Press.

Enders, W. (2004) Applied Econometric Time Series. Hoboken, N.J: John Wiley \& Sons.

Engle, R.F., and Granger, C.W.J. (1987) 'Co-Integration and Error Correction: Representation, Estimation, and Testing', Econometrica, 55(2), pp. 251-276.

Epley, N. and Gilovch, T. (2016) 'The mechanics of motivated reasoning', Journal of Economic Perspectives, 30(3), pp. 133-40.

Ericsson, N.R., and MacKinnon, J.G. (2002) 'Distributions of Error Correction Tests for Cointegration', Econometrics Journal, 5(2), pp. 285-318.

Erikson, R.S., MacKuen, M.D. and Stimson, J.A. (2002) The Macro Polity. Cambridge: Cambridge University Press.

Fernández-Albertos, J. (2012) Democracia intervenida: politicas económicas en la Gran Recesión. Madrid: Catarata.

Fishman, R.M. (2020) 'Spain in Comparative Perspective: Contributors of the Spanish Case to Comparative Political Analysis' in Muro, D. and Lago, I. (eds.) The Oxford Handbook of Spanish Politics, chapter 2. Oxford: Oxford University Press

Grant, T. and Lebo, M.J. (2016) 'Error correction methods with political time series', Political Analysis, 24(1), pp. 3-30.

Green, J. and Jennings, W.J. (2012) 'Valence as macro-competence: An analysis of mood in party competence evaluations in Great Britain', British Journal of Political Science, 42(2), pp. 311-343. 
Gunther, R. and Montero, J.R. (2009) The Politics of Spain. Cambridge: Cambridge University Press.

Gunther, R., Montero, J.R. and Puhle, H.J (2016) 'Intermediation, voting and citizen participation: Evidence from in-depth and longitudinal analyses of Spain' in Gunther, R., Beck, P.A., Magalhaes, P.C. and Moreno, A. (eds.) Voting in Old and New Democracies. London: Routledge, pp. 230-72.

Hakhverdian, A. (2010) 'Political Representation and its Mechanisms: A Dynamic LeftRight Approach for the United Kingdom, 1976-2006', British Journal of Political Science, 40(4), pp. 835-56.

Keele, L., Linn, S. and Webb, C.M. (2016) 'Treating Time with All Due Seriousness', Political Analysis, 24(1), pp. 31-41.

King, A.S. (2010) The British Constitution. Oxford: Oxford University Press.

King, A.S. (ed) (2002) Leaders' personalities and the outcomes of democratic elections. Oxford: Oxford University Press.

Laver, M., Benoit, K. and Garry, J. (2003) 'Extracting policy positions from political texts using words as data', American Political Science Review, 97(2), pp. 311-331.

Lowe, W. (2008) 'Understanding wordscores', Political Analysis, 16(4), pp. 356-71.

MacKinnon, J.G. (1994) 'Asymptotic Distribution Functions for Unit-Root and Cointegration Tests', Journal of Business \& Economic Statistics, 12(2), pp. 167-176.

May, J.D. (1978) 'Defining Democracy: A Bid for Coherence and Consensus', Political Studies, 26(1), pp. 1-14. doi: 10.1111/j.1467-9248.1978.tb01516.x.

McGann, A., Dellepiane-Avallaneda, S. and Bartle, J. (2019) 'Parrallel lines? Policy mood in a plurinational democracy', Electoral Studies, 58, pp. 48-57.

Méndez-Lago, M. and Martínez, A. (2002) 'Political Representation in Spain: An Empirical Analysis of the Perception of Citizens and MPs'. Journal of Legislative Studies, 8(1): 63-90.

Orriols, L. and Cordero, G. (2016) 'The breakdown of the Spanish two-party system: the upsurge of Podemos and Ciudadanos in the 2015 general election', South European Society and Politics, 21(4), pp. 469-492.

Orriols, L. and Rico, G. (2014) 'El clima de opinión' in Anduiza, E.; Bosch, A.; Orriols, L. and Rico, G. (eds) Elecciones generales 2011, pp. 63-82. Madrid: CIS.

Page, B.I. and Jones, C.C. (1979) 'Reciprocal effects of policy preferences, party loyalties and the vote', American Political Science Review 73(4), pp. 1071-1089.

Page, B.I. and Shapiro, R.Y. (1992) The Rational Public: Fifty Years of Trends in Americans' Policy Preferences. Chicago: The University of Chicago Press.

Powell, C. (2009) 'Leopoldo Calvo Sotelo: corrigiendo el rumbo de una democracia amenazada', Revista de Occidente, no. 336, pp. 41-58. 
Powell, G.B. (2000) Elections as instruments of democracy: Majoritarian and proportional visions. New Haven: Yale University Press.

Rodríguez-Teruel, J. and Barrio, A. (2018b) 'Ciudadanos: el asalto al centro' in Llera, F.; Baras, M. and Montabes, J. (eds.) Las elecciones generales de 2015 y 2016. Madrid: CIS, pp. 249-272.

Rodríguez-Teruel, J.; Barrio, A. and Barberà, O. (2018a) 'Podemos: de partido anticasta a confluencia de la plurinacionalidad' in Llera, F.; Baras, M. and Montabes, J. (eds.) Las elecciones generales de 2015 y 2016. Madrid: CIS, pp: 207-226.

Romero-Vidal, X. (2019) 'Two temperatures for one thermostat: The evolution of policy attitudes and support for independence in Catalonia (1991-2018)', Nations and Nationalism. Early View Online Version. https://doi.org/10.1111/nana.12559

Rose, R. (1980) Do Parties Make a Difference? London: Macmillan.

Sánchez-Cuenca, I. (2012) Años de cambios, años de crisis. Ocho años de gobierno socialista 2004-2011. Madrid: Catarata.

Schuman, H. and Presser, S. (1996) Questions and answers in attitude surveys: Experiments on question form, wording and context. Thousand Oaks: Sage.

Soroka, S.N. and Wlezien, C. (2010) Degrees of Democracy: Politics, Public Opinion, and Policy, Cambridge: Cambridge University Press.

Stimson, J.A. (1999) Public Opinion in America: Moods, Cycles and Sings. Boulder, CO: Westview Press.

Stimson, J.A. (2004) Tides of Consent: How Public Opinion Shapes American Politics. Cambridge: Cambridge University Press.

Stimson, J.A., MacKuen, M.D. and Erikson, R.S. (1995) 'Dynamic representation', American Political Science Review, 89(3), 543-65.

Stimson, J.A., Thiébaut, C. and Tiberj, V. (2012) 'The evolution of policy attitudes in France', European Union Politics, vol. 13(2), pp. 293-316.

Stokes, D.E. (1963) 'Spatial models of party competition', American Political Science Review, 57(2), pp. 368-77.

Strøm, K. (1990) 'A behavioural theory of competitive political parties', American Journal of Political Science, 34(2), pp. 565-98.

Torcal, M. (2014) 'The Decline of Political Trust in Spain and Portugal: Economic Performance or Political Responsiveness?' in American Behavioral Scientist, 58(12), pp. 1542-1567.

Urquizu, I. (2014) 'La segunda legislatura de Rodríguez Zapatero' in Anduiza, E.;

Bosch, A.; Orriols, L. and Rico, G. (eds) Elecciones generales 2011, pp. 29-46. Madrid: CIS.

Wilson, C.A. (2000) 'Policy regimes and policy change', Journal of Public Policy, 20(3), pp. 247-274. 
Wlezien, C. (1995) 'The public as thermostat: Dynamics of preferences for spending', American Journal of Political Science, 39(4), pp. 981-1000.

Wlezien, C. and Soroka, S.N. (2015b) 'Electoral systems and opinion representation', Representation, 51(3), pp. 273-285.

Wlezien, C. and Soroka, S.N. (2015a) 'The majoritarian and proportional visions and democratic responsiveness', Electoral studies, 40, pp. 539-547.

Zaller, J.R. and Feldman, S. (1992) 'A simple theory of the survey response: Answering questions versus revealing preferences', American Journal of Political Science, 36(3), pp. 579-6. 


\section{Appendix. The dyads ratio algorithm}

Responses are scored from high (most left or Labour) and to low (most right or Conservative) responses. It is straightforward to code these items since the parties have taken consistent (opposing) positions. Assigning the "wrong" polarities to responses makes no difference to the estimates of mood - it simply results in negative factor loadings that alert us to a coding error (Stimson 1999).

All preferences are expressed as an index of preferences:

$$
\text { Index of preferences }=\frac{\sum_{i=1}^{N} \text { Left preferences }}{\sum_{i=1}^{N} \text { Left }+ \text { Right preferences }} \times 100
$$

These indexes reflect then balance of left-right preferences on controversial issues. They are fed into the dyads ratio algorithm in order to estimate mood.

The policy mood represents a double summation across both individuals and issues (Stimson 1999). The first step is, therefore, to aggregate responses for each individual series. These are expressed as an index of preferences, which is simply leftwing preferences as a proportion of all substantive (i.e. left and right) responses:

$$
\text { Index of preferences }=\frac{\text { left responses }}{\text { left }+ \text { right responses }}
$$

These indexes reflect then the balance of left-right preferences on each controversial issue as measured by specific items. These are the raw data that are fed into the dyads ratio algorithm to estimate mood. The algorithm expresses these indexes as ratios at two time points ('dyads'): 


$$
R i j=\frac{x t+i}{x t+j}
$$

These dyads have an expected value of 1.0 and can be averaged to produce a rough estimate of underlying preferences $(\mathrm{Pt})$. This step enables us to complete the double summation by averaging across individual item series. The algorithm calculates all the possible dyads for each series $\mathrm{x}_{\mathrm{tk}}$ iteratively and averages the

$$
\mathrm{P}_{\mathrm{t}}=\frac{\sum_{\mathrm{k}=1}^{\mathrm{N}} \mathrm{X}_{\mathrm{tk}}}{\mathrm{N}}
$$

Not all items are equally valid indicators of underlying preferences. Each series is therefore weighted by their estimated validity $\left(\mathrm{h}_{\mathrm{i}}^{2}\right)$ :

$$
\mathrm{P}_{\mathrm{t}}=\frac{\sum_{\mathrm{k}=1}^{\mathrm{N}} \mathrm{h}_{\mathrm{i}}^{2} \mathrm{X}_{\mathrm{tk}}}{\mathrm{h}^{2} \mathrm{~N}}
$$

Transforming the index of preferences into ratios causes the original metric to be lost. This is reintroduced by a standardisation of the latent scale in terms of the validityweighted means and standard deviations of the input items (Stimson 1999). The individual preference series are scored as per cent left over per cent left plus per cent right. The extracted policy mood has the same interpretation. Accordingly, 50 is the neutral point. Values above 50 indicate net left preferences and those below 50 indicate net right preferences.

The series can also be smoothed using an exponential smoothing operator:

$$
Y_{t}=\alpha x_{t}+(1-\alpha) x_{t-1}
$$


Where $\mathrm{y}$ is the smoothed version of $\mathrm{x}$ (Stimson 1999, p. 135). Smoothing can have a dramatic effect where - as in the early years of this study - data is in short supply.

In this paper we use the unsmoothed estimates, since these are more sensitive to both policy and economic conditions. 
Table 1. Data sources

\begin{tabular}{lllll} 
Source & \multicolumn{2}{c}{ Questions } & \multicolumn{2}{c}{ Administrations } \\
& $\mathrm{N}$ & per cent & $\mathrm{N}$ & per cent \\
CIS & 72 & 56.7 & 1320 & 78.5 \\
Eurobarometer & 5 & 3.9 & 170 & 10.2 \\
ESS & 10 & 7.9 & 57 & 3.4 \\
RofG & 17 & 13.4 & 34 & 2.0 \\
WVS & 23 & 18.1 & 100 & 6.0 \\
Total & & & &
\end{tabular}


Table 2. Item loadings of policy mood, 1978-2017

$\begin{array}{ll}\text { Variable name } & \text { Source } \\ & \\ \text { UNIFYEU } & \text { Eurobarometer } \\ \text { PUBLSPEND1 } & \text { CIS } \\ \text { LR2 } & \text { CIS } \\ \text { SPENDCUT4 } & \text { CIS } \\ \text { GOVPROTECT6 } & \text { CIS } \\ \text { PUBLSPEND10 } & \text { CIS } \\ \text { SPENDCUT13 } & \text { CIS } \\ \text { PUBLSPEND9 } & \text { CIS } \\ \text { SPENDCUT3 } & \text { CIS } \\ \text { PUBLSPEND2 } & \text { CIS } \\ \text { GOVPROTECT } & \text { CIS } \\ \text { PUBLSPEND11 } & \text { CIS } \\ \text { SPENDCUT1 } & \text { CIS } \\ \text { PUBLSPEND3 } & \text { CIS } \\ \text { GOVPROTECT1 } & \text { CIS }\end{array}$

Abbreviated question

N Factor

loadings

For or against European unification

Government spending on infrastructure

Left-right self-placement

Government spending on public security

Government protection for immigrants

Government spending on culture

Government spending on culture

Government spending on transport and communications

Government spending on defence

Government spending on social security and pensions

Government spending on old people living alone

0.93

$27 \quad 0.92$

$35 \quad 0.893$

$14 \quad 0.88$

$10 \quad 0.86$

$18 \quad 0.85$

$11 \quad 0.84$

$23 \quad 0.77$

$20 \quad 0.77$

Government spending on the environment

$\begin{array}{lll}\text { Government spending on infrastructure } & 20 & 0.71\end{array}$

$\begin{array}{lll}\text { Government spending on public security } & 25 & 0.61\end{array}$

Government spending on pensioners

$\begin{array}{ll}25 & 0.61 \\ 10 & 0.58\end{array}$

Source: authors' estimate 
Table 3. Models of mood, 1978-2017 (unsmoothed estimates)

Model 3.1 Model 3.2 Model 3.3 Model 3.4

Error correction

$\begin{array}{cccc}-0.13 * & -0.33 * \star & -0.38 * \star \star & -0.34 * \star \star \\ (0.07) & (0.13) & (0.11) & (0.11)\end{array}$

Incumbent

$-1.47 *$

$-0.67$

(0.08)

(1.02)

Log Unemployment

Short-term
Long-term

$\begin{array}{ccc}-1.59 & -1.07 & -0.07 \\ (3.96) & (3.84) & (3.52) \\ 3.03 & 3.61 * & 4.06 * \star \\ (2.21) & (2.01) & (1.84)\end{array}$

LOg NMGE

Short-term
Long-term

14.20

11.25

(14.79)

(15.57)

$-16.11$

$-19.75 * \star$

(8.17)
9.90
$(13.49)$
$-18.80 * *$
$(7.45)$

(9.92)

Dummy 2004

$6.11 * * *$

(2.23)

Constant

9. 03 *

$72.41 *$

$86.77 * \star *$

$79.46 * \star \star$

(4.87)

$(38.73)$

(31.70)

(29.03)

Adjusted $\mathrm{R}^{2}$

0.13

0.16

38

38

0.17

0.31

$\mathrm{N}$

2.40

2.36

2.34

38

Root MSE

2.64

1.15

0.28

0.40

2.13

Breusch Godfrey Chi2

0.10

9.45

0.53

0.09

8.85

0.93

8.90

0.77

Portmanteau Q

0.95

0.94

9.70

Prob

3.79

0.16

0.02

0.92

ARCHLM Chi2

0.05

0.69

0.90

0.12

0.73 
Table 4. Models of vote intentions 1978-2017

\begin{tabular}{|c|c|c|}
\hline & Left & Right \\
\hline Error correction & $\begin{array}{l}-0.23 \star \\
(0.12)\end{array}$ & $\begin{array}{l}-0.19 * \star \\
(0.09)\end{array}$ \\
\hline Log Unsmoothed mood & & \\
\hline Short-term & $\begin{array}{l}41.04 * \star \\
(16.92)\end{array}$ & $\begin{array}{l}-38.49 * \star \star \\
(13.23)\end{array}$ \\
\hline Long-term & $\begin{array}{l}14.04 * \star \\
(7.41)\end{array}$ & $\begin{array}{l}-17.58 * * \\
(13.23)\end{array}$ \\
\hline Constant & $\begin{array}{l}-54.31 \star \\
(31.33)\end{array}$ & $\begin{array}{l}77.19 * \star \\
(17.26)\end{array}$ \\
\hline $\begin{array}{l}\text { Adjusted } \mathrm{R}^{2} \\
\mathrm{~N} \\
\text { Root MSE }\end{array}$ & $\begin{array}{l}0.27 \\
38 \\
3.40\end{array}$ & $\begin{array}{l}0.24 \\
38 \\
2.93\end{array}$ \\
\hline $\begin{array}{l}\text { Breusch-Godfrey } \\
\text { Prob }\end{array}$ & $\begin{array}{l}0.06 \\
0.81\end{array}$ & $\begin{array}{l}3.20 \\
0.07\end{array}$ \\
\hline $\begin{array}{l}\text { Portmanteau } Q \\
\text { Prob }\end{array}$ & $\begin{array}{l}19.37 \\
0.31\end{array}$ & $\begin{array}{l}13.07 \\
0.73\end{array}$ \\
\hline $\begin{array}{l}\text { ARCHLM Chi2 } \\
\text { Prob }\end{array}$ & $\begin{array}{l}0.83 \\
0.36\end{array}$ & $\begin{array}{l}1.70 \\
0.19\end{array}$ \\
\hline
\end{tabular}


Table 5. Model of policy, 1978-2018

\begin{tabular}{|c|c|c|c|}
\hline & Model 5.1 & Model 5.2 & Model 5 . \\
\hline Error correction & $\begin{array}{l}-0.16 * \star \star \\
(0.05)\end{array}$ & $\begin{array}{c}-0.11 \\
(0.07)\end{array}$ & $\begin{array}{c}-0.21 \star \\
(0.11)\end{array}$ \\
\hline Incumbent & $\begin{array}{l}0.99 * \star \\
(0.48)\end{array}$ & $\begin{array}{c}0.66 * \\
(0.39)\end{array}$ & $\begin{array}{l}0.91 * \star \\
(0.45)\end{array}$ \\
\hline Log unemployed & & & \\
\hline Short-term & & $\begin{array}{l}6.15 * \star \star \\
(1.33)\end{array}$ & $\begin{array}{l}6.86 \star \star \star \\
(1.43)\end{array}$ \\
\hline Long-term & & $\begin{array}{c}0.22 \\
(0.82)\end{array}$ & $\begin{array}{c}0.65 \\
(1.04)\end{array}$ \\
\hline Log unsmoothed mood & & & \\
\hline Short-term & & & $\begin{array}{c}4.41 \\
(5.56)\end{array}$ \\
\hline Long-term & & & $\begin{array}{l}-4.21 \\
(0.45)\end{array}$ \\
\hline Constant & $\begin{array}{l}6.12 \star \star \star \\
(1.74)\end{array}$ & $\begin{array}{l}3.57 \star \star \\
(1.49)\end{array}$ & $\begin{array}{c}23.69 \\
(19.80)\end{array}$ \\
\hline Adjusted $\mathrm{R}^{2}$ & 0.23 & 0.51 & 0.51 \\
\hline $\mathrm{N}$ & 40 & 40 & 38 \\
\hline MSE & 1.41 & 1.12 & 1.13 \\
\hline Breusch-Godfrey & 1.63 & 0.02 & 0.16 \\
\hline Prob & 0.20 & 0.98 & 0.69 \\
\hline Portmanteau $\mathrm{Q}$ & 18.37 & 22.57 & 20.13 \\
\hline Prob & 0.43 & 0.21 & 0.27 \\
\hline ARCHLM Chi2 & 0.05 & 3.58 & 2.63 \\
\hline Prob & 0.82 & 0.06 & 0.11 \\
\hline
\end{tabular}


Figure 1. The number of administrations of items per year

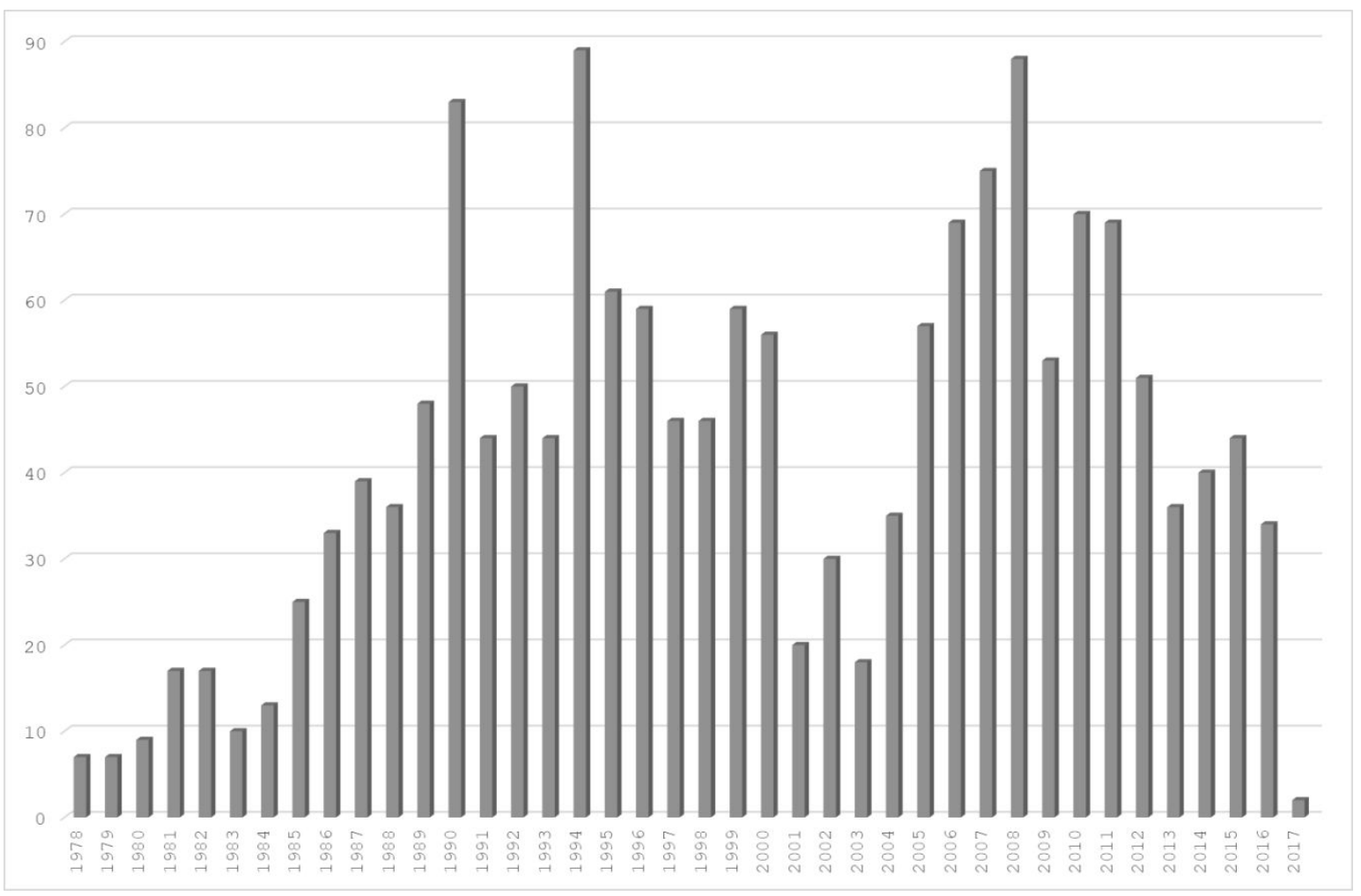


Figure 2. Non-military government expenditure as a proportion of GDP in Spain, 1976-2017

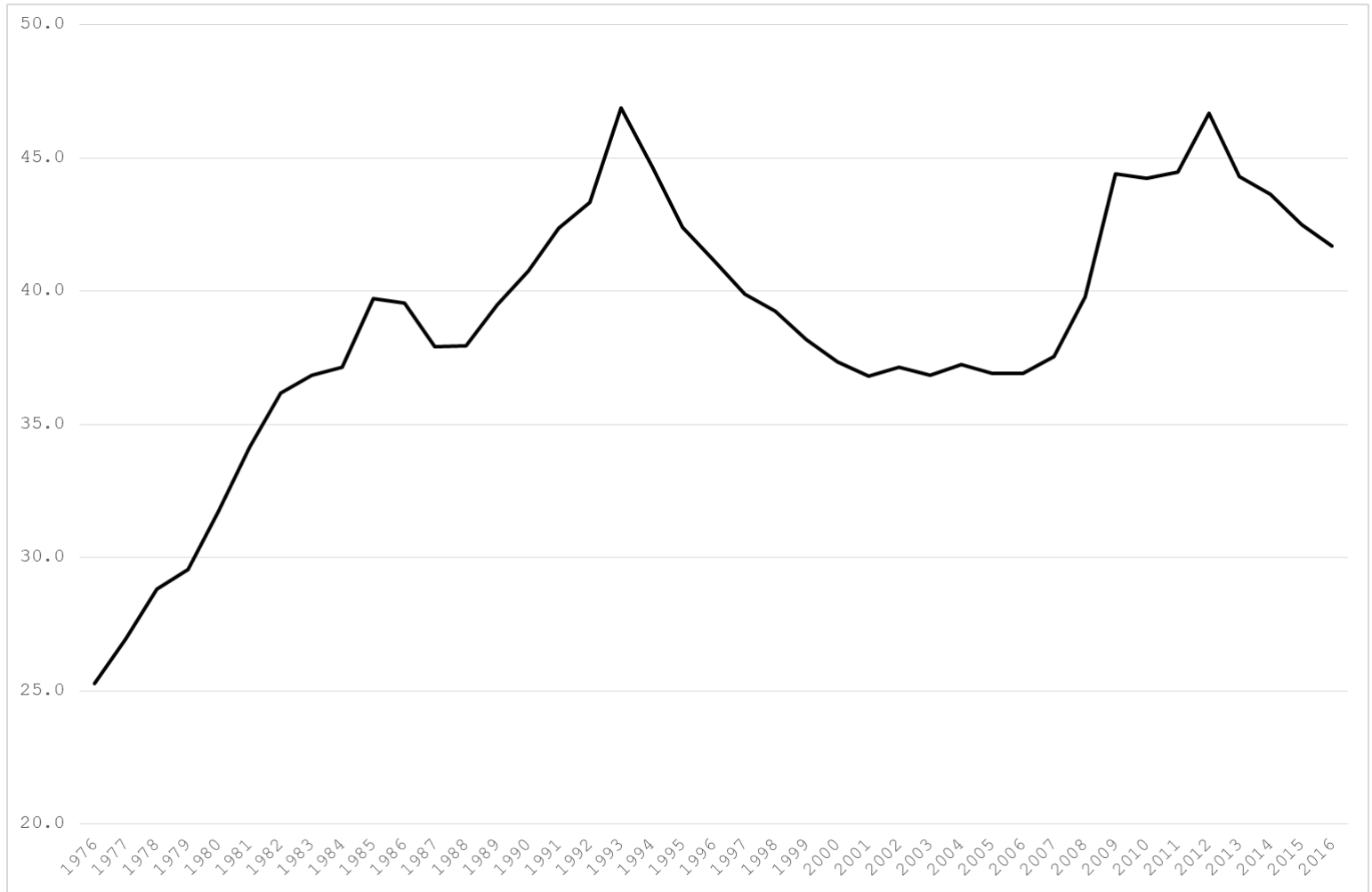


Figure 3. Changes in government spending as a proportion fo GDP by government (NMGE), 1976-2017

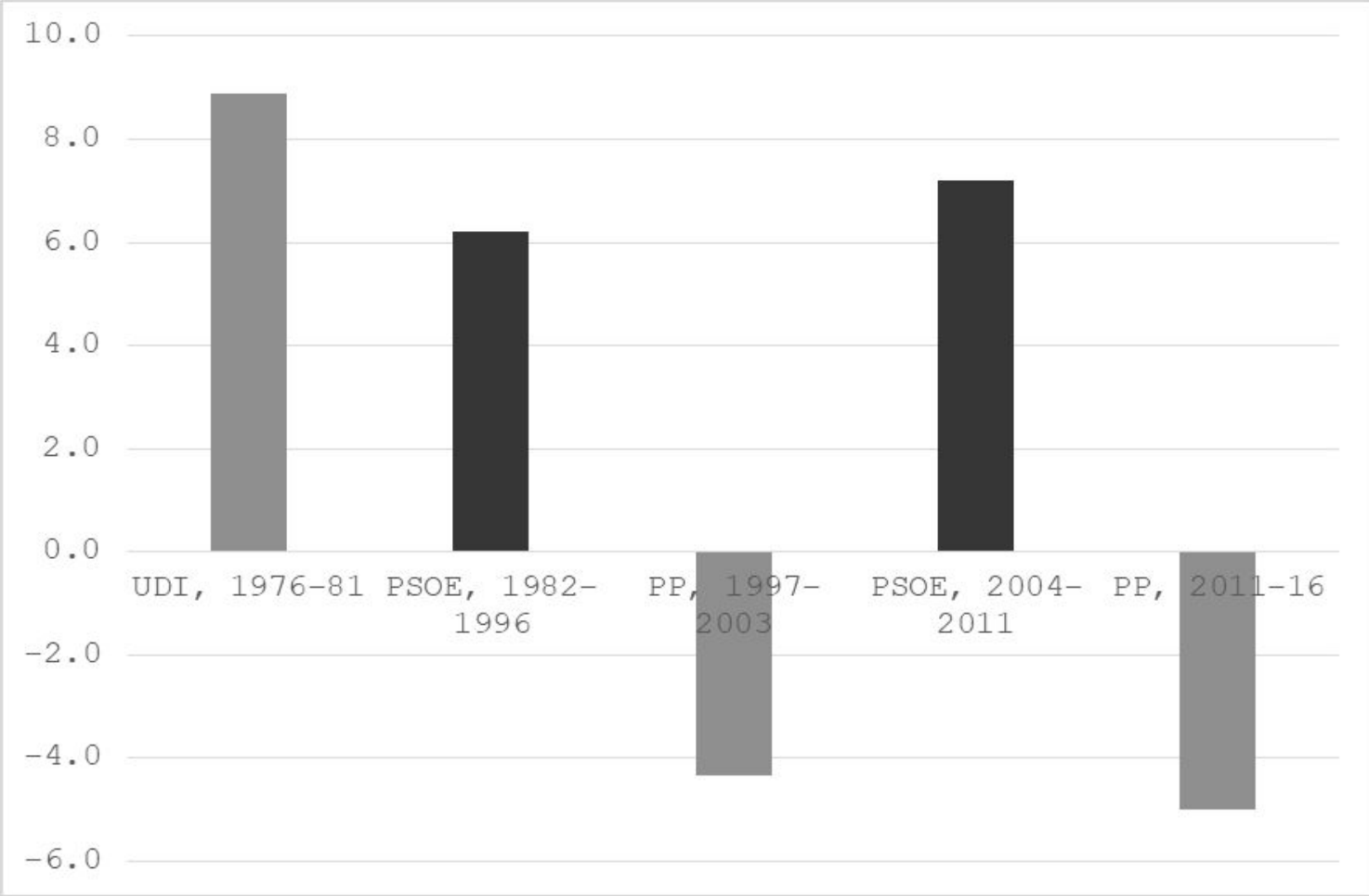


Figure 4. The Spanish policy mood, 1978-2017

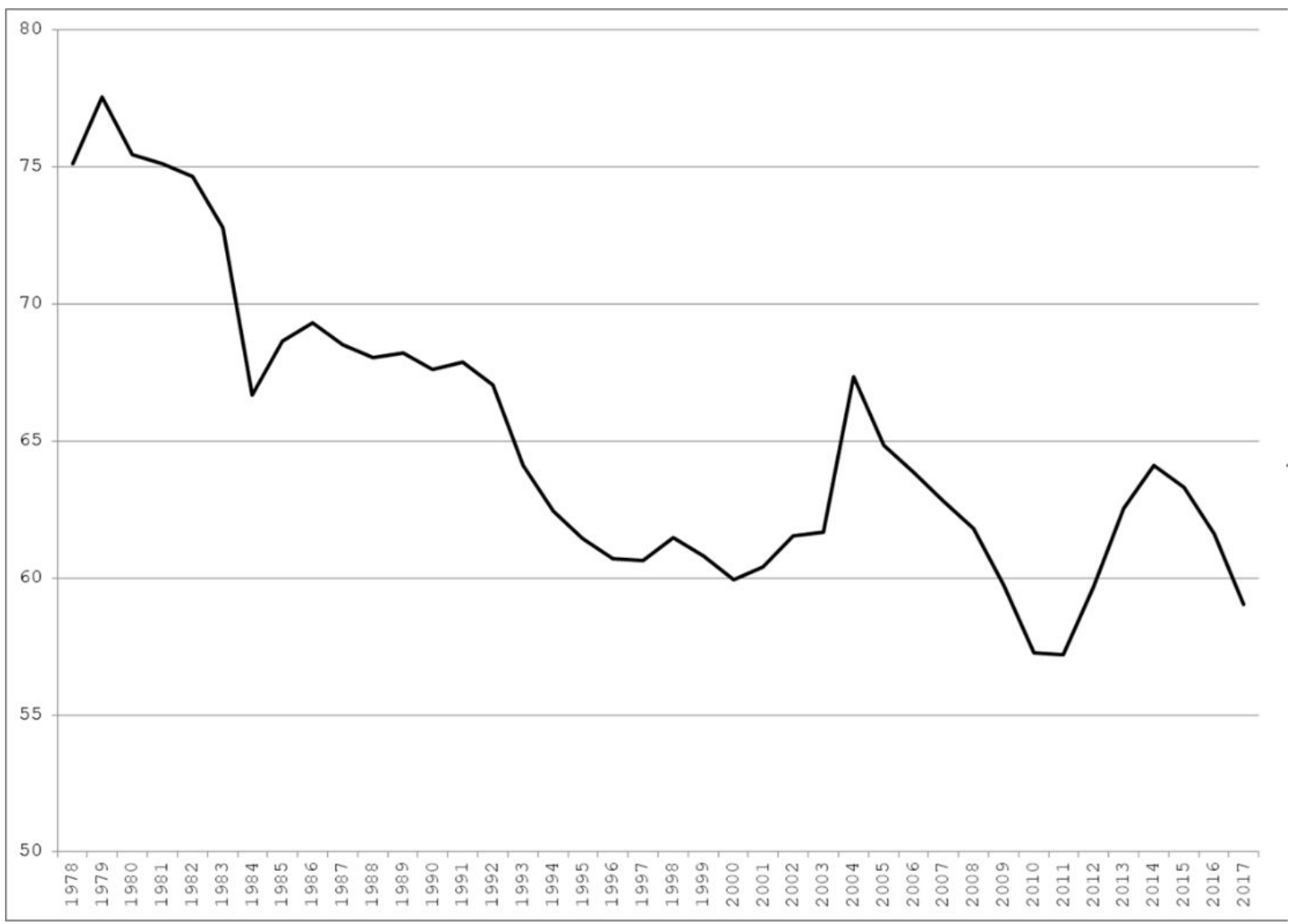


Figure 5. Changes in the policy mood by government, 1978-2017

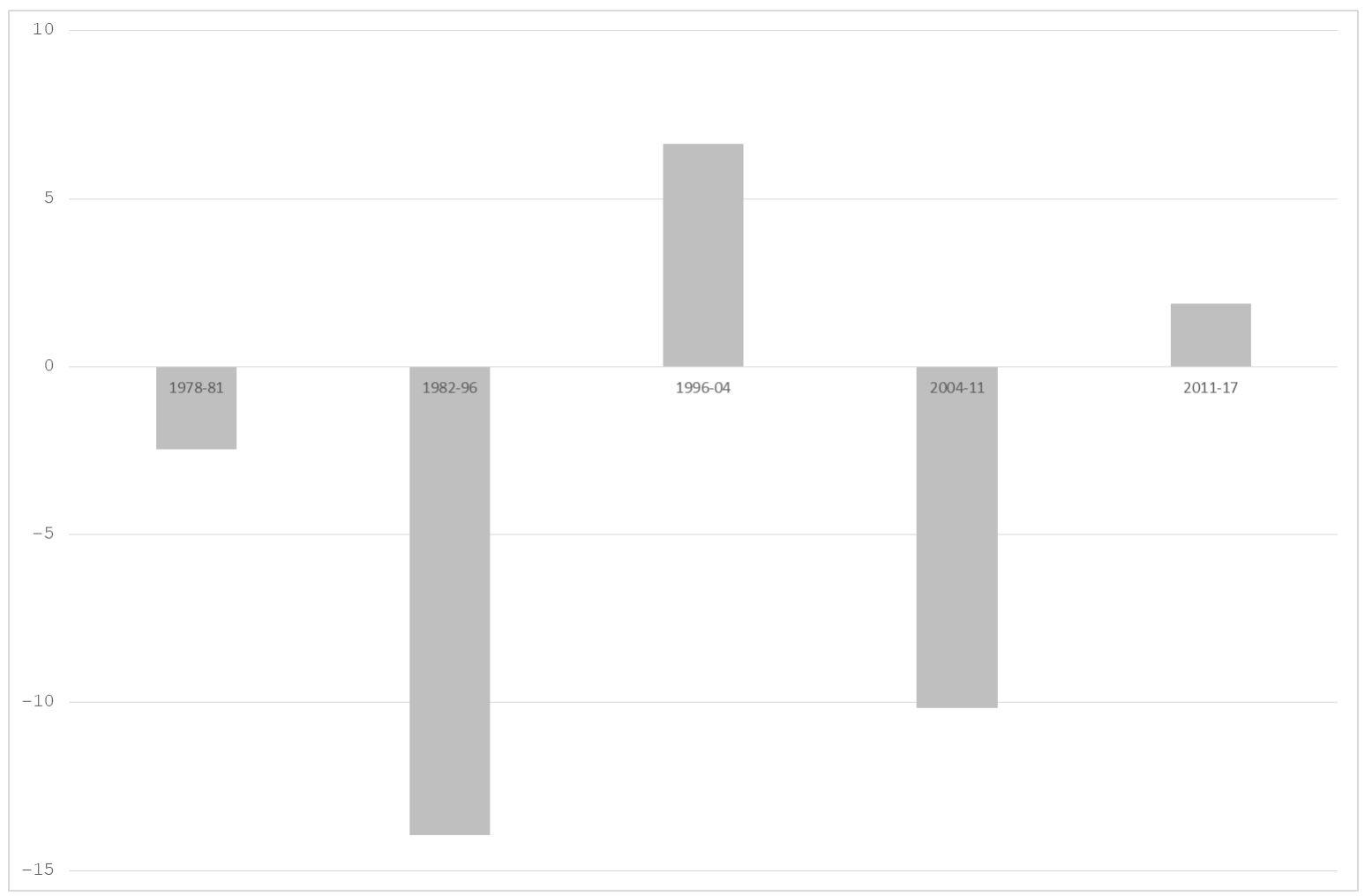

